\title{
A KOOPERATÍV TANULÁS SZEREPE A TANÁRI KOMPETENCIÁK FEJLESZTÉSBEN
}

\author{
VARGA ÉVA \\ az Eszterházy Károly Főiskola \\ adjunktusa \\ vargae@ektf.hu
}

A tanulmány egy projektben való részvétel után született meg, melynek keretein belül módszertan oktatóként a kooperativ tanulással foglalkoztunk, majd kipróbáltunk a némettanár képzésben. A központi fogalmak értelmezését követöen sor kerül a kooperatív tanulás jellemzöinek összefoglalására. Fontos szerepet kap a megváltozott tanári szerep és a tanári kompetenciák vizsgálta. A cikk második részében a gyakorlatban kipróbált módszerek részletes bemutatására kerül sor.

\section{Bevezetés}

Folyamatosan átalakuló világunkban az oktatásban is szükségszerúen bekövetkeznek változások, új célok jelennek meg, melyeket a tradicionális módszerekkel már nem lehet megvalósítani. A fejlődést kísérő kihívások új kompetenciák, gazdagabb módszertani kultúra kialakulását igénylik a tanári pálya minden területén. Szükség van a jövő nyelvtanárainak képzésében és továbbképzésében is új tanulási-tanítási technikák megismerésére, elsajátítására. Kezdő tanárként különösen fontos az új utak keresése és kipróbálása. A HEFOP 3.2.2. program keretében folyó fejlesztési munkák során föiskolánkon a német nyelvtanárok képzésében a kooperatív tanulás kérdései kerültek a figyelem középpontjába. A kooperatív tanulással kapcsolatban régóta folynak kutatások, ezek összegzéseképpen felsorolhatók a kooperatív tanulás legjellegzetesebb elemei; a megváltozott tanári szerep, a csoportalkotás lehetőségei. Tanulmányomban azt a mühelymunkát szeretném bemutatni, amelyet német szakos tanárjelöltekkel végeztem a nyelvpedagógia szemináriumok keretein belül egyrészt a kooperatív tanulás megismertetése, másrészt gyakorlati alkalmazása terén.

A program első szakaszában, a „képzők képzésében” előadásokon, tréningeken, illetve később továbbképzéseken ismerkedtünk új tanulási módszerekkel és kompetenciaterületekkel. Ekkor vettem részt azon a felkészítő tréningen, amelyen pszichológus kollégáink segítségével kooperatív technikákkal ismerkedtünk kooperatív munkaformák felhasználásával. A program második szakaszában ezt az új módszert kellett beépíteni a módszertan szemináriumainkba. A frissen szerzett tapasztalataimat rögtön ki tudtam próbálni és átadhattam hallgatóimnak is. A harma- 
dik szakaszban a hallgatók tanítási gyakorlataik során a közoktatásban próbálták ki a kooperatív munkaformákat.

\section{A képzés során használt központi fogalmak értelmezése}

\section{Kompetencia-alapú oktatás}

Mai megváltozott és felgyorsult világunkban a hagyományos tanulási formák már nem felelnek meg a kor elvárásainak. Egyre több kritika éri az oktatást tartalma és módszerei miatt. A mai nemzedéket már nem lehet kizárólag a régi, hagyományos, elsősorban frontális módszerekkel tanítani, ezt a nagy tapasztalattal rendelkező pedagógusok is megerősítik. A tanítással kapcsolatos szemléletváltozás egyik fontos területe a kompetencia-alapú oktatás, melyet ugyan gyakran még maguk a pedagógusok is csak tanulnak, ízlelgetnek, de egyre több jó példát lehet már látni a közoktatásban és a felsőoktatásban, remélhetően a felnőttoktatásban is teret hódít majd. Sok tanár örömmel próbálja ki, de vannak természetesen ellenállások is, hiszen sokan félnek az ismeretlentől, nem szívesen adják fel évek óta használt módszereiket. A kompetencia-alapú oktatás az ismeretek aktív alkalmazását tüzi ki célul, ezért lehetséges tanítási stratégiái között kitüntetett szerepet kap a projektmunka és a kooperatív tanulás. A tanárképzés egyik célja tehát az, hogy olyan tanárok kerüljenek ki az iskolákba, akik maguk is képesek a kompetencia-alapú oktatásra, akik diákjaikat fel tudják készíteni az élethosszig tartó tanulásra. Ehhez mindenképpen szükség van arra is, hogy a jövő tanárai maguk is rendelkezzenek az új kompetenciákkal és ismerjék azokat az utakat, amelyek ide vezetnek, „hiszen az a tanár tudja az oktatásban magáévá tenni az új szemléletet, akit már a képzésben is hasonló hatás ért." (Falus és Kotschy, 2006, 68. o.)

A kompetencia fogalma összetett, de a szakmai közmegegyezés a következő meghatározás körül kezd kialakulni: „A kompetencia a pszichikus képződmények olyan rendszere, amely felöleli az egyénnek egy adott területre vonatkozó ismereteit, nézeteit, motívumait, gyakorlati készségeit, s ezáltal lehetővé teszi az eredményes tevékenységet... A pedagógiai kompetenciák a tudás, nézetek és gyakorlati készségek ötvözetei, amelyek lehetővé teszik, hogy a pedagógus egy adott területen sikeresen elláthassa feladatát." (Falus, 2005, 6-7. o.)

Nem véletlen tehát, hogy tartalmilag a tanári kompetenciákat három területen (ismeretek, nézetek/attitüdök és tevékenységek/képességek) kell/kellett kidolgozni. Fontos, hogy a tudás mellett pedagógiai attitüdök is megjelenjenek és fontos szerepet kapjanak a tanárképzésben. 


\section{Kooperativ tanulás}

„A kooperatív tanulás olyan tanulásszervezési mód, amelyben az ismeretek átadása, a kognitív képességek, a szociális motívumok és képességek, valamint a tanulási motívumok fejlesztése egyidejü és egyenrangú cél." (Józsa és Székely, 2004, 340. o.)

„A kooperatív életszemlélet kölcsönös tiszteletre alapozott együttmüködést és a közösség minden tagjának egyéni teljesítményét előtérbe állító szemléletet jelent." (Óhidy, 2005, 100. o.)

A kooperatív tanulás tulajdonképpen tanulásszervezési módszerként fogható fel, sőt egyik legnevesebb szakértője, Norm Green egyenesen filozófiának nevezi. Bár Magyarországon még viszonylag újnak mondható ez a módszer, szoros összefüggése a több évtizede alkalmazott csoportmunkával biztos bázist jelent bevezetéséhez. Az utóbbi években már olyan tanulmányokat, tapasztalati beszámolókat olvashatunk, amely a kooperatív tanulás fogalmát említik.

\section{A kooperatív tanulási formák jellemzői}

Amikor a kooperatív tanulásról beszélünk, mindig felmerül a kérdés, hogy miben jelent mást a kooperatív csoportmunka a hagyományos csoportmunkához képest. (A felkészítő tréningen mi is ezt a kérdést kaptuk elsőként.) Bár a kooperatív tanulás több eleme a projektmunkából vagy a kommunikatív nyelvoktatásban gyakran alkalmazott csoportmunkából már ismerős, elterjedtek a szakirodalomban a Green által megfogalmazott és a kooperatív tanulással foglalkozó szakemberek, tanárok által gyakran idézett különbségek a kooperatív tanulás és a hagyományos csoportmunka között.

Az első a pozitív függőségi viszony vagy épitö egymásrautaltság. Ez azt jelenti, hogy ha a csoport bármelyik tagja nem tudja elvégezni a feladatát, az egész csoport eredménytelen lesz. Éppen ezért nemcsak arra kell törekedniük, hogy a saját feladatukat teljesítsék, hanem segítséget kell nyújtaniuk a többieknek abban, hogy ők is el tudják végezni a feladatukat. A csoport tagjai különböző szerepeket kapnak, melyeknek szintén eleget kell tenniük az eredményes közös munka érdekében. Ilyen szerep pl. a szószóló, írnok, az időfelelős, a csendfelelös stb. A pozitív függőség jelenti talán a kooperatív tanulási formák legfontosabb elemét.

A második a személyes felelösség, mely azt jelenti, hogy az adott feladatról mindenkinek egyénileg kell beszámolnia, illetve a feladatot minden csoportnak el kell végeznie, tehát mindenkit be kell vonni a tanulási folyamatba. Mivel a csoport összetétele heterogén, a kooperatív tanulás nem azt jelenti, hogy a csoport minden egyes tagjának egyforma mértékben kell kivenni a részét a munkából, a követelményszinteket, elvárásokat egyénre kell szabni. Mindenki úgy dolgozik, ahogyan tud. Éppen ezért válhat szükségessé a csoporton belüli kooperáció, amely lehetővé teszi, hogy a csoporttagok segítsenek egymásnak. Mindenki tehetséges valamiben, ez gyakran ki is derül a kooperatív tanulási technikák alkalmazása során. 
A harmadik jellegzetesség, hogy a kooperatív tanulás a csoporttagok között közvetlen (szemtöl-szembe) interakciót igényel, folyamatos kommunikációra van szükség egymással, ebbe beletartozik pl. a másik egyén segítése, dicsérete is.

Negyedik, nagyon fontos elemként említhetô a szociális kompetencia fejleszté$s e$, mely a csoport tagjainak együttműködő képességét fejleszti, a társas érintkezés szabályainak rendszeres használatát igényli. „Nem nehéz belátni, hogy a szociális kompetenciák fejlesztése (pl. kommunikáció, segítségnyújtás, együttmüködés) eredményesebb, amikor a tanulók együtt dolgoznak, hiszen ebben az esetben teljesen normális és magától értetődő az, hogy a diákok megosztják egymással ötleteiket, megbeszélik gondolataikat, együttmüködnek. Egy ilyen környezetben rengeteg lehetőség nyílik a segítségadásra, barátkozásra, a társas érintkezéshez szükséges készségek gyakorlására." (Bacskay et al., 2008, 13. o.) Sőt megjelennek olyan készségek és képességek is, mint pl. a szervezőképesség, a tolerancia, a humor, a vidámság.

Végül utolsó elemként az értékelés emelhető ki. Az értékelés folyamatosan jelen van, nem csak a végeredmény fontos, hanem a tanulási folyamatok értékelése is kiemelkedő szerepet kap. A csoportoknak meg kell beszélniük, hogyan érték el a célt, a csoporttagok munkája milyen szerepet játszott az egész folyamatban, hangsúlyosabbá válik a folyamat egészének ellenőrzése, értékelése.

A kooperatív tanulási formáknak több pozitív hatása is megfigyelhető. Az együttmüködés javítja az eredményeket, nő a csoport tagjainak önbizalma, önbecsülése, a tanuláshoz való hozzáállás pozitívabb lesz, a motiváltság javul, a diákok felfedezik, hogy jó együtt dolgozni más képességü és más tulajdonságú társaikkal, megtanulják elfogadni a különbségeket (tolerancia), javul a kommunikációs készség, fejlödik a kreativitás, a problémamegoldó képesség. A gyengébb képességü tanulók is szóhoz jutnak.

\section{Tanári feladatok és kompetenciák a kooperatív tanulási folyamatban}

A tanárképzés szempontjából a kooperatív tanulási technikák nagyon fontos pontja a megváltozott tanárszerep. A jövő tanárai sajnos még nagyon gyakran maguk is először a módszertani szemináriumokon szembesülnek új tanítási módszerekkel. Időnként egy egyszerü csoportmunka is problémát jelent számukra. Sokan közülük még ahhoz vannak hozzászokva, hogy a tanár végigbeszéli az órát, „leadja” az anyagot, majd azt meg kell tanulni és végül valamilyen formában számon kérik tőlük. Sokszor csak elöre megfogalmazott és betanult válaszokat lehet adni a tanári kérdésekre. Pedig az aktív tanulás sokkal eredményesebb. A tanár feladata, hogy megteremtse diákjai számára a megfelelő tanulási környezetet, amelyben szükség van aktív együttmüködésre, együtt gondolkodásra, ötletek, vélemények egymás közötti kicserélésére, összehasonlítására, a diákok tanulási tapasztalatokat szerezhetnek, hiszen ebben a tanulási formában nagyon fontos az is, hogyan jutottak el a csoportok 
az eredményig, nem kizárólag a végeredmény a lényeg. Az egész tanulási folyamatot a párbeszédnek kell jellemeznie, amelyben a diákok természetesen a tanártól is kérdezhetnek. Ez nem jelenti azt, hogy a tanár időnként nem magyarázhatja el saját gondolatmenetét, nem mondhatja el saját álláspontját, de nem állhat csak ebből a tanítási óra. A kooperatív tanulás tehát mindenképpen megváltozott tanári szerepeket és kompetenciákat kíván, melyeket a tanároknak is meg kell tanulniuk, és a gyakorlatban folyamatosan fejleszteni kell. A tanár részéröl a kooperatív technikákkal felépített órák előkészítése rengeteg munkát követel. A látszólag könnyedebb, játékosabb, több zajjal és mozgással járó óra mögött rengeteg felkészülés, előkészület van. A tanár kreativitása kiemelkedő szerepet játszik ezeken a tanórákon. A tanári feladatok közé tartozik a célok egyértelmü megfogalmazása, a csoportok nagyságának és összetételének meghatározása, a feladatok adása, az anyagok kiválasztása és előkészítése, a csoportok viselkedésének és munkájának megfigyelése, segítségnyújtás, beavatkozás (ha szükséges), az értékelés megszervezése, melyben az önértékelésnek kiemelkedően fontos szerepe van. A kooperatív tanulási formák alkalmazása esetén a tanár szerepe a tanórán jelentősen megváltozik. Szervező és irányító szerepet tölt be, annak ellenére, hogy az órákon háttérben marad. Nagyon jól összefoglalja a megváltozott tanári szerep lényegét a következö néhány pont:

„A szociális képességek hatékony osztálytermi fejlesztése tehát a hagyományostól eltérő feladatokat kíván meg a pedagógusoktól:

- minden gyerekkel szemben nyitott, pozitív elvárással, bizalommal van;

- empatikus, megértő attitüd jellemzi, el tudja fogadni a tanulók ötleteit, kezdeményezéseit, sőt azt is, ha javaslatait elutasítják a diákok;

- együttmüködő, ösztönző partnerré válik, aki nem kívülről irányít, hanem belülről látja meg, hogy mikor, kinek van szüksége segítségre;

- az osztálytermet úgy kell kialakítania, hogy a csoporttagok könnyedén kapcsolatba tudjanak kerülni egymással." (Bacskay et al., 2008, 12. o.)

Ezekkel a technikákkal lehetőség nyílik a tárgyak közötti integrációra, sőt a tanárok egymás között kooperációjára is.

\section{A csoportalkotás lehetőségei}

Nagyon fontos szerepet játszanak a kooperatív módon szervezett órákon a párok és csoportok, illetve a csoportalkotás lehetőségei, hiszen a jól müködő csoport a kulcsa az effektív munkának. Az ideális csoport 3-5 főből (mások szerint 4-6 föből) áll. Bizonyos helyzetekben célszerü tudatosan összeállítani a csoportokat, pl. képességek alapján, lehetőleg úgy, hogy ezt a diákok ne vegyék észre. Időnként a diákokra lehet hagyni a csoportalkotást. Gyakran azonban nyugodtan rá lehet bízni a csoportok létrejöttét a véletlenre, mint esetünkben is a német szakos tanárjelölteknél. Ilyenkor játékos feladatok vethetök be, melyek különösen kedveltté váltak a hallgatók 
körében. Később, vizsgatanításaikat hospitálva gyakran visszaköszöntek, visszaköszönnek a csoportalkotás játékos lehetőségei.

Néhány módszer, melyeket részben én is kipróbáltam a felkészítő tréningeken:

- A hallgatók gombokat húztak joghurtos pohárból. Akik egyforma gombokat kaptak, egy csoportba kerültek.

- Szétvágott képeslapokat kellett összerakniuk, mint a puzzle-t, ez volt a csoportalkotás alapja.

- Számokat kaptak a hallgatók, 1-töl 3-ig. Akik egyforma számot kaptak, egy csoportot alkottak.

- Sort alkottak születési dátum szerint, a „legfiatalabbak”, a „legidősebbek” és a köztük lévők alkottak egy-egy csoportot.

- A csoportalkotás alapja az volt, hogy ki szeretne tanárként dolgozni a diploma megszerzése után és ki nem. A „bizonytalanok” alkották a harmadik csoportot.

- Közös érdeklődési terület, kedvenc étel, szín, születési évszak alapján is alkottunk csoportokat. A lehetőségeknek csak a fantáziánk szabhat határt.

A csoportalkotásnál szükség van a tanári leleményességre is, hiszen nem mindig kiszámítható előre a csoport létszáma, illetve váratlan aránytalanságoknál ötletesen kell eljárni. Számomra örökre emlékezetes az egyik hallgató spontán felkiáltása, miután a játék során számára észrevétlenül csoportokba rendeződtek: „Ez egy igazi varázslat!"

A csoportok mindig bizonyos ideig dolgoznak csak együtt, utána érdemes újabb csoportokat létrehozni, hiszen így olyanok is összekerülnek, akik korábban soha nem dolgoztak együtt.

\section{Kooperatív technikák a módszertan órákon}

Fontos megjegyezni, amennyiben kooperatív technikákat használunk az órákon, az nem azt jelenti, hogy a többi módszert mellőzzük. A kooperatív tanulási formákkal csak kiegészítjük a meglévő módszertani repertoárunkat, nem pedig lecseréljük az egészet. A módszertan órákon két, a tananyagban meglévő, azelőtt előadás formájában átadott téma részben kooperatív technikákkal történő feldolgozására vállalkoztam. Tettem ezt azért, mert ez volt a feladatom a programban, vagyis be kellett építeni a meglévő tanmenetbe a kooperatív technikákat, úgy, hogy közben „haladni” kellett az elméleti anyaggal. Másrészt pedig sok éves nyelvgyakorlat órákon szerzett tapasztalataim alapján azzal tisztában voltam, hogy nyelvóra kooperatív technikákkal színesítve csakis eredményes lehet. Kíváncsi voltam, hogyan müködnek ismeret-átadó órák ilyen tanulási módszerrel megszervezve. A felkészülés rendkívül sok időt igényel a tanártól, különösen az ezen a téren kezdő tanártól. Csak az első óra után könnyebbültem meg, miután láttam, hogy tényleg müködik. 
Nagyon fontos ezeken az órákon az ülésrend. Mindig úgy kell berendezni a termet, hogy a hallgatók lássák egymást. Az óra elején félkörben ültek, óra közben a terem különböző részeiben csoportokban, majd a prezentálásnál, megbeszélésnél újra félkörben. A kooperatív csoportokra jellemző szerepek kiosztását a hallgatókra bíztam.

A feldolgozásra szánt témakörök a következők voltak:

- A nyelvtan szerepe a német nyelv tanulásának folyamatában.

- Az országismeret (Landeskunde) szerepe a németórákon.

A témák feldolgozására különböző kooperatív technikákat alkalmaztunk.

\section{Gömb módszer}

Téma: A nyelvtan szerepe a német nyelv tanulásának folyamatában. (Bevezetés a témába)

Az óra elején feltett kérdések a következők voltak:

- Milyen szerepet játszik a nyelvtantanítás az idegen nyelv tanításának folyamatában?

- Milyennek ítéli meg a nyelvtantanítást az iskolákban?

- Milyen problémákkal kell megküzdeni a tanároknak a nyelvtan tanításakor?

Elöször mindenki önállóan válaszolta meg a kérdéseket. Két oszlopba rendszerezték a hallgatók a gondolataikat:

1. A következő tapasztalataim, ismereteim vannak a témával kapcsolatban

2. A következő kérdéseim vannak a témával kapcsolatban

A cél az iskolai tapasztalatok, előző tanulmányok alapján a már ismert tudás rendszerezése, további kérdések felvetése, problémák megfogalmazása volt.

Következő lépésben minden hallgató egy társával folytatta a töprengést az elöző pontban feltett kérdések alapján.

Az volt a cél, hogy tapasztalatokat, ötleteket cseréljenek, egymást segítsék, közös tudást hozzanak létre, közös kérdéseket fogalmazzanak meg, problémák vessenek fel.

A harmadik lépésben minden pár eldönthette, hogy melyikük képviseli a közös véleményüket, ki összegzi és mondja el a többieknek a gondolataikat. A végén lehetőség volt egymás kiegészítésére, föleg akkor, ha különböző tapasztalataik voltak a párok tagjainak.

Végül nagycsoportos beszélgetés keretében a különböző véleményekből öszszeállt az „egész”, amelyet ki lehetett egészíteni, illetve rendszerezni kellett.

„Egy megy, három marad” módszer

A következő duplaórán került sor a folytatásra. Az óra témája a következő volt: A nyelvtan fogalmának különbözö meghatározási lehetöségei. 
Az elöző óra anyagának felidézése, összefoglalása után, mely egyébként frontálisan történt, négyes csoportokra osztottam a hallgatókat. Mindegyik csoport ugyanazt a feladatlapot kapta, amelyen párosítani kellett kijelentéseket a nyelvtan fogalmának három különböző meghatározásához. A kész feladatot a csoportok bemutatták egymásnak úgy, hogy csoportonként egy-egy tanuló helyet cserélt egy másik csoporttaggal. A visszatérők beszámoltak a látottakról, összevetették a saját megoldásukkal. Különböző megoldások megvitatása, véleménycsere volt a cél. Plénum előtt számoltak be, értékeltek a csoportok.

\section{„Indiánbeszélgetés” módszer}

A fogalmak definiálásánál használtuk ezt a módszert. Három fogalomhoz hármas csoportok szükségesek. Mindenki húzott egy fogalmat. Meg kellett értenie, tanulnia a saját definícióját, méghozzá úgy, hogy a többieknek is át tudja adni a lényegét a saját csoportjában. Az indiánbeszélgetés azt jelenti, hogy a következő csak akkor jut szóhoz, ha a saját szavaival újra megfogalmazza azt, amit az előtte szóló mondott. Így a csoport tagjainak mindenképpen figyelniük kell egymásra. Az óra végén a táblánál tanári irányítással készítettünk összefoglalást táblázat formájában.

\section{„Gondolkozz - Beszéld meg párban” módszer}

A kommunikatív nyelvtanitás nyelvtanközvetitésének ismérveit kapták meg párok, melyeket értelmezni kellett. A párok húztak egy-egy jellemzőt annak magyarázatával, példákkal, először csendben értelmezték ezeket a diákok, majd pedig a párjukkal megbeszélték. A végén a párok ismertették a többi párral az eredményeiket. Felépítésében ez a módszer hasonlít a „Gömb módszerhez”, annyi különbséggel, hogy ott először mindenki önállóan keresi a megoldást.

\section{Képtár-látogatás}

A téma az induktív és deduktív nyelvtantanítás volt. A csoportok sorshúzással döntötték el, ki melyik nyelvtantanítási eljárást dolgozza fel. Az induktív, illetve a deduktív nyelvtantanítás jellegzetességeit összefoglalva megkapták a csoportok. A feladatuk az volt, hogy ennek alapján a megkapott nyelvtani jelenség (tárgyeset) megtanításához egy nagyon rövid, mini óra vázlatát készítsék el. A csoportok megtekintették a többi csoport munkáját. Megbeszélték a látottakat és értékelték a munkát.

\section{Beszélgetö kör}

A hallgatók elöször elgondolkodtak azon, hogy számukra mit jelent ez a fogalom: „Landeskunde”. A diákok a teremben körben ültek, sorban elmondták, amit a témáról gondolnak. 
Jigsaw-módszer vagy szakértöi mozaik

A Jigsaw-módszer a kooperatív technikák egyik legelterjedtebb módszere, mely több változatban létezik. Lényege a „tanítva tanulás”. Ennek a tanulási módszernek 3 szakasza van. A csoportok mindegyike ugyanazt az új ismeretet tartalmazó szöveget kapja, mely részekre van felosztva. Minden csoporttag kap egy szövegrészt, amelyet egyénileg elolvas, megért, jegyzeteket készít hozzá, ill. kérdéseket fogalmaz meg. A következő lépésben az azonos szövegrészt választó hallgatók összeülnek, „szakértői csoportokat” alkotnak, vagyis megbeszélik, értelmezik az olvasottakat, közös vázlatot írnak, a magyarázathoz szükséges anyagokat készítenek. Ezután mindenki visszatér a saját csoportjába és megtanítja a többieknek a feldolgozott anyagát. A csoportok plakátokat készítenek, amelyeket a plénum előtt mutatnak be. Ezeket természetesen ki lehet egészíteni, meg lehet vitatni. A módszer egyik előnye, hogy minden csoporttag egyszerre tanuló és a tanár is. Úgy kell tervezni az órát, hogy a feladat időigényes. Az óra témája a következő volt: Hogyan változott a ,Landeskunde” fogalma a nyelvtanitás történetének során? (Kognitiver Ansatz. Kommunikativer Ansatz. Interkultureller Ansatz) Minden témához több oldalnyi, szakkönyvekből kimásolt szöveget kaptak a hallgatók.

\section{Összegzés}

Szeretnék visszatérni egy pillanatra az írás címére: A kooperatív tanulás szerepe a tanári kompetenciák fejlesztésében. Zárásként álljon itt a KKK-ban (képzési és kimeneti követelmények) megfogalmazott tanári mesterképzésben legfontosabb kilenc kulcskompetencia, minden tanári szak számára kötelező tanári kompetenciák felsorolása:

1. A tanulói személyiség fejlesztése

2. A tanulói csoportok, közösségek alakulásának segítése, fejlesztése

3. A pedagógiai folyamat tervezése

4. A tanulók müveltségének, készségeinek és képességeinek fejlesztése a tudás felhasználásával

5. Az egész életen át tartó tanulást megalapozó kompetenciák fejlesztése

6. A tanulási folyamat szervezése és irányítása

7. A pedagógiai értékelés változatos eszközeinek alkalmazása

8. Szakmai együttmüködés és kommunikáció

9. Önmüvelés, elkötelezettség a szakmai fejlödésre

Ha megnézzük ezt a kompetencialistát, láthatjuk, hogy a kooperatív tanulási technikákkal valamennyi tanári kompetencia jól fejleszthető. Míg a hallgatók tanulói szerepben vannak, addig csak néhány kompetencia kap fontos szerepet számukra (pl. 1,2,4,5), de abban az esetben, amikor a hallgatók tanári szerepben próbálják ki ezeket a technikákat (erre láttam több példát is a gyakorló tanítások során és ez a valódi célja ezeknek a szemináriumoknak), a többi tanári kompetencia is előtérbe 
kerül. Különösen jól fejleszthető ebben az esetben a pedagógiai folyamat tervezése, a tanulási folyamat szervezése és irányítása, a pedagógiai értékelés, szakmai együttmüködés és az önmüvelés.

A bemutatott és kipróbált órákon a legfontosabb cél a hallgatók szempontjából a saját élmény megszerzése volt, annak átélése, hogyan müködik egy kooperatív csoport, hogyan lehet a saját tudást a csoporton belül közös tudássá tenni, miközben a közös gondolkodás, az egymásra figyelés, egymás meghallgatása, a különböző vélemények elfogadása nélkülözhetetlen a siker érdekében. Ezek mind olyan kompetenciák, amelyekre a ma emberének életében, munkájában szüksége van. A kooperatív tanulási formák segítségével, annak jellegéből adódóan tehát mindegyik kompetencia területén fejleszthetjük a jövő tanárait, akik előtt nem kis feladat áll: fel kell készíteni a felnövekvő generációt az új kihívásokra, de ehhez önmaguknak is felkészültnek kell lenniük. Sikernek könyvelem el a hallgatók pozitív visszajelzéseit, próbálkozásaikat a gyakorlóiskolában, és azt a tényt, hogy már több hallgató választotta szakdolgozata témájául a kooperatív tanulási technikákat.

\section{Irodalom}

Bacskay Beáta, Lénárd Sándor, Rapos Nóra, L. Ritók Nóra (2008): Kooperativ tanulás. Oktatási programcsomag a pedagógusképzés számára. Educatio Társadalmi Szolgáltató Közhasznú Társaság, Budapest.

Benda József (2002a): A kooperatív pedagógia szocializációs sikerei és lehetőségei Magyarországon I. Új Pedagógiai Szemle, 9. sz. 26-37.

Benda József (2002b): A kooperatív pedagógia szocializációs sikerei és lehetőségei Magyarországon II. Új Pedagógiai Szemle, 10. sz. 21-33.

Falus Iván (2005): Képesítési követelmények - kompetenciák - sztenderdek. Pedagógusképzés, 1. sz. 5-16.

Falus Iván, Kotschy Beáta (2006): Kompetenciaalapú tanárképzés: divatos jelszó vagy a megújulás eszköze? Pedagógusképzés, 3-4. sz. 67-75.

Józsa Krisztián, Székely Györgyi (2004): Kísérlet a kooperatív tanulás alkalmazására a matematika tanítása során. Magyar Pedagógia, 3. sz. 339-362.

Green, N., Green, K. (2007): Kooperatives Lernen im Klassenraum und im Kollegium. Das Trainingsbuch. Kallmeyer-Klett, Seelze-Velber.

Kagan, S. (2001): Kooperatív tanulás. Önkonet Kft., Budapest.

Nagy József, Zsolnai Anikó (2001): Szociális kompetencia és nevelés. In: Báthory Zoltán és Falus Iván (szerk.): Tanulmányok a neveléstudomány köréből. Osiris Kiadó, Budapest. 251-269.

Óhidy Andrea (2005): Az eredményes tanítási óra jellemzői. Kooperatív tanulási formák a gyakorlatban. Új Pedagógiai Szemle, 12. sz. 100-108.

Wicke, Rainer E. (2009): Alter Wein in neuen Schläuchen? Wie heißt das nun wirklich Kooperatives Lernen oder Gruppenarbeit? Fremdsprache Deutsch. Zeitschrift für die Praxis des Deutschunterrichts. Heft, Nr. 41. 40-44. 